\title{
Granite Installation Company Owner Struck by Falling Granite Slab
}

\section{Incident Number: 15KY020}

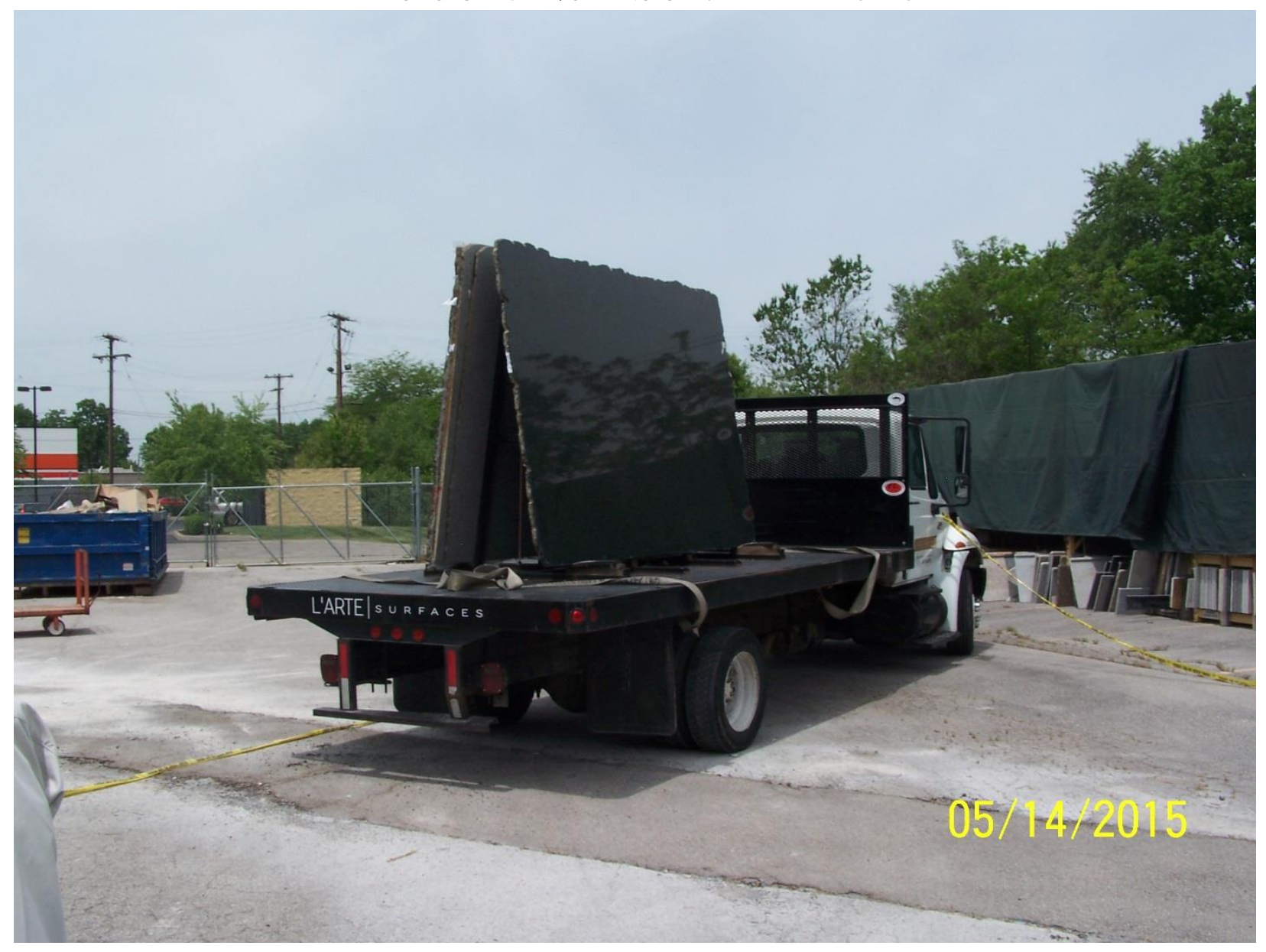

Kentucky Fatality Assessment and Control Evaluation Program Kentucky Injury Prevention and Research Center 333 Waller Avenue

Suite 242

Lexington, Kentucky 40504

Phone: 859-323-2981

Fax: 859-257-3909

www.mc.uky.edu/kiprc/programs/face.html

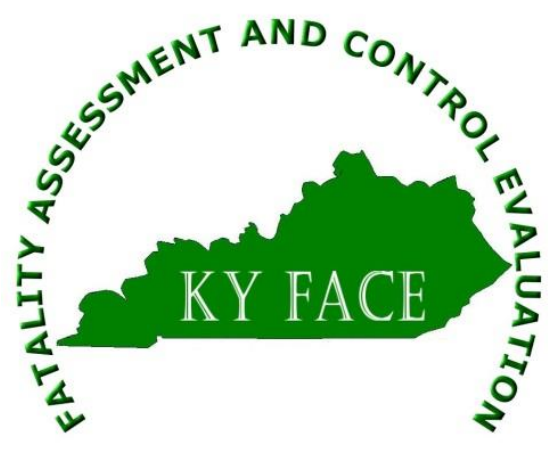




\section{Kentucky Fatality Assessment and Control Evaluation (FACE) Program \\ Incident Number: 15KY020 \\ Release Date: October 6, 2015 \\ Subject: Granite Installation Company Owner Struck by Falling Granite Slab}

\section{Introduction}

On Thursday, May 14, 2015, a clear and windy spring morning, a male company owner and a male forklift operator were unloading slabs of granite from a delivery truck. The forklift operator was unloading the slabs with a forklift equipped with a boom and a clamp designed to move the granite. The owner (victim) walked by the forklift to the area where the granite was to be stored. The forklift operator gently set the granite next to the victim who was standing directly in the middle of the large piece of granite guiding it into place (within the fall shadow zone). Once the granite was on the ground, the clamp automatically released. The granite shifted, striking the victim in the head and pinning him under the $1000 \mathrm{lb}$. granite slab. At the time of the incident, the wind speed was $15.0 \mathrm{mph}$ and a gust of wind registered at $21.9 \mathrm{mph}$ from the east. Weather could have been a factor in this fatality.

The forklift driver, delivery driver, and another employee tried to remove the granite from the victim; EMS was immediately called and arrived within minutes. The victim was declared dead at the scene.

To prevent future occurrences of similar incidents, the following recommendations have been made:

Recommendation No. 1: Employers should identify a fall shadow zone, and restrict employees from placing themselves in that zone, while stone is being loaded, unloaded or moved.

Recommendation No. 2: Employers should provide written safety programs and training for their employees.

Recommendation No. 3: Employers should provide hazard recognition training for their employees.

Recommendation No. 4: Employers should always use stone slab storage racks designed by engineers with individual compartments to support the granite and marble slabs.

Recommendation No. 5: Spotters should remain in full view of equipment operators at all times while wearing personal protective equipment.

Recommendation No. 6: A guideline or regulation for slab transfer during windy environmental conditions should be established. 


\section{Employer}

The employer was a small family business that fabricated and installed granite for kitchens and baths. The company had 4 employees, opened in 2004 and had been in business for 10 years.

\section{Written Safety Programs and Training}

The employer did not have any written safety policies or a handbook. The employees interviewed stated they received on-the-job training by the owner that included forklift operation and slab storage. Staying out of the fall shadow zone was not included in the training.

\section{$\underline{\text { Victim }}$}

The victim was a 57-year-old U.S. citizen born in Fuzhou, China. He was a married father of two, a high school graduate, and owner of the company. He was 5 foot 4 inches tall. The granite was 121 inches long by 79 inches high, weighing 1000 lbs.

\section{Incident Scene}

The incident scene was the company parking lot. There was a makeshift storage area on the right hand side of the lot. The storage area had a roof and tarps on two sides, leaving the front side exposed to outside winds. This is where granite was placed as it was unloaded from trucks. The area where the incident occurred was outside the covered storage area and inside a chain link fence and in an open area to the left of the covered storage area.

\section{Weather}

May 14, 2015, was a clear day with temperatures ranging from 62 to 74 degrees Fahrenheit. At the time of the incident, the wind speed was $15.0 \mathrm{mph}$ and a gust of wind registered at $21.9 \mathrm{mph}$ from the east. Weather is believed to be a factor in this fatality. According to the Marble Institute of America ${ }^{1}$ training video, even the slightest breeze is dangerous when moving stone slabs.

\section{$\underline{\text { Investigation }}$}

The Kentucky Fatality Assessment and Control Evaluation Program discovered through the local media that a fatality had occurred involving granite crushing a worker. An investigation was conducted.

On Thursday, May 14, 2015, a granite delivery driver arrived at the employer's business around 9:30 am, to deliver previously ordered granite. The victim and the forklift operator brought out a forklift truck to unload five slabs of granite. The forklift had a boom with a slab clamp to move the granite slabs (see photos \#1 and \#2).

The forklift operator drove the forklift to the flatbed truck and positioned the forklift so that the truck driver could reach the boom and place the clamp securely in the middle of the $1000 \mathrm{lb}$. slab of granite. Once the slab was secured, the forklift operator took the slab to the storage area, 
placed it on the concrete, and returned for the next piece. The forklift operator unloaded four pieces of granite. The fifth and final piece of granite was unloaded from the truck. This slab measured 121 inches long by 79 inches tall and 1000 lbs. The forklift operator stated he had set the last slab of granite on the ground. (Once the granite is on the ground the clamp automatically releases.) The forklift operator stated that the victim stood directly in the middle of the large piece of granite guiding it into place, which was his usual practice. The forklift driver backed away once the clamp released. The victim was positioned directly in the fall shadow of the granite slab. Before the victim could move from the fall shadow, a gust of wind may have caused the granite to shift, striking the victim in the head and pinning him under the granite slab.

The forklift operator, another employee, and the delivery driver immediately worked together to remove the granite from the victim. Emergency Medical Services were called at 10:19 am and arrived on the scene minutes later. The victim was pronounced dead at the scene.

\section{Cause of Death}

The cause of death was blunt force head trauma.

\section{$\underline{\text { Recommendations and Discussions }}$}

Recommendation No. 1: Employers should identify a fall shadow zone, and restrict employees from placing themselves in that zone, while stone is being loaded, unloaded or moved. 1

OSHA defines the fall shadow zone as "the area on both sides of the slab where the slab could land and topple if it were to fall." The higher the slab is lifted from the ground, the larger the fall zone. Standing outside of the fall shadow at either end of the slab is the best practice to prevent being crushed or hit with the stone slab.

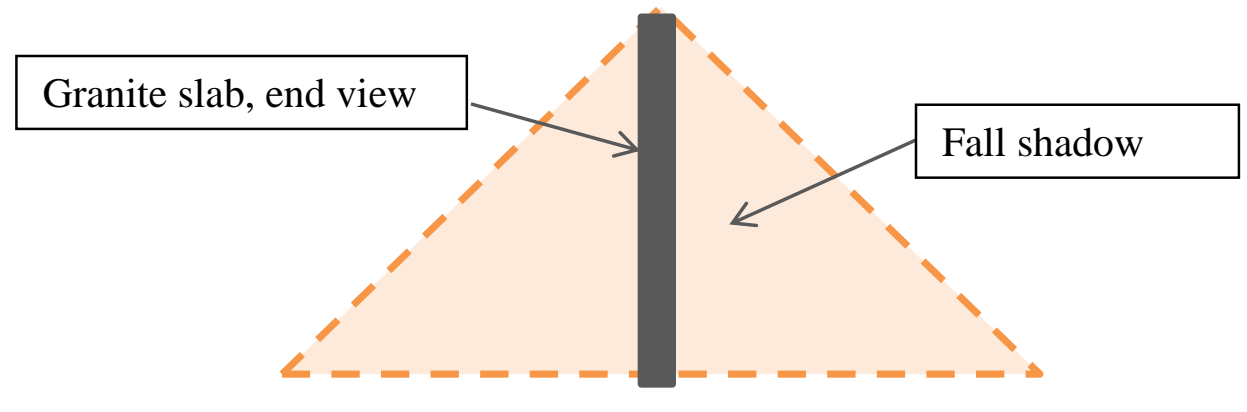

\section{Recommendation No. 2: Employers should provide written safety programs and training for their employees. ${ }^{2}$}

Written safety programs should include standard operating procedures for safe stone handling such as inspection of the equipment used to move the slabs, and use of personal protective equipment. OSHA requires that all industries provide written programs and training for their employees, not only to be in compliance with OSHA, but also to educate employees how to work 
safely and avoid injury.

Recommendation No. 3: Employers should provide hazard recognition training for their employees. ${ }^{3}$

Employers should provide hazard recognition training on slab transfer, safe storing and handling, slab cutting, and use of hazardous material such as solvents, polyesters, epoxies and adhesives, sealers, and dusts.

Recommendation No. 4: Employers should always use stone slab storage racks designed by engineers with individual compartments to support the granite and marble slabs. ${ }^{4}$

Employers should use engineered heavy duty stone slab storage racks to protect their employees and their product. Individual compartments ensure integrity and protect each slab. Slab storage racks also protect against slabs being blown over. The wind speed at the time of the incident was $21.9 \mathrm{mph}$ and may have contributed to the slab tipping over.

Recommendation No. 5: Spotters should remain in full view of equipment operators at all times while wearing personal protective equipment.

Employees need to remain in full view so equipment operators are aware of where they are. Employees need to wear reflective vests, steel toed shoes, hard hat and safety glasses as well as gloves when transporting stone slabs.

Recommendation No. 6: A guideline or regulation for slab transfer during windy environmental conditions should be established.

Regulatory agencies such as the federal Occupational Safety and Health Administration (OSHA) and organizations such as Marble Institute of America should consider establishing a regulation or guideline on transferring stone slabs during windy conditions.

\section{$\underline{\text { Keywords }}$}

Safe Slab Handling

Granite

Stone Slab

\section{$\underline{\text { References }}$}

${ }^{1}$ Chapter IV: Safe Slab Handling. Safety in the Stone Business, Revised Edition. The Marble Institute. Page 72012.

${ }^{2}$ Training Requirements in OSHA Standards. OSHA.gov https://www.osha.gov/Publications/osha2254.pdf 
${ }^{3}$ Hazards of Transporting, Unloading, Storing and Handling Granite, Marble and Stone Slabs. OSHA.gov safety and health bulletins. https://www.osha.gov/dts/shib/shib081208.html

${ }^{4}$ Hazards Associated with Transporting Granite and Marble Slabs. US Department of Labor Occupational Safety and Health Administration https://www.osha.gov/dts/shib/shib090805.pdf

Acknowledgements

The Kentucky FACE program would like to thank the Marble Institute of America (MIA) and KY OSH for their assistance with this report.

The Kentucky Fatality Assessment \& Control Evaluation Program (FACE) is funded by grant 2U60OH008483-11 from the Centers for Disease Control and Prevention and the National Institute for Occupational Safety and Health. The purpose of FACE is to aid in the research and prevention of occupational fatalities by evaluating events leading to, during, and after a work related fatality. Recommendations are made to help employers and employees have a safer work environment. For more information about FACE and KIPRC, please visit our website: www.kiprc.uky.edu 


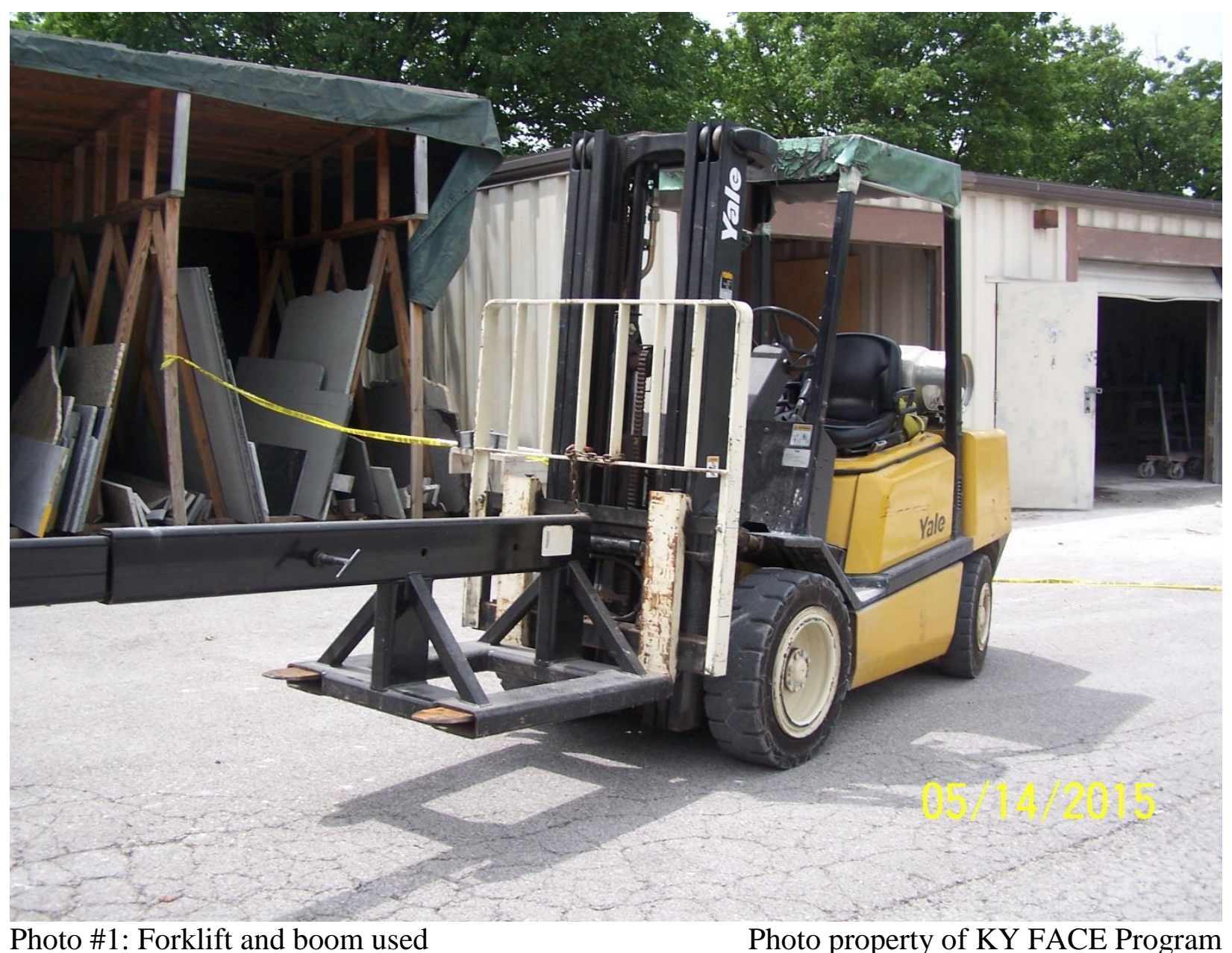




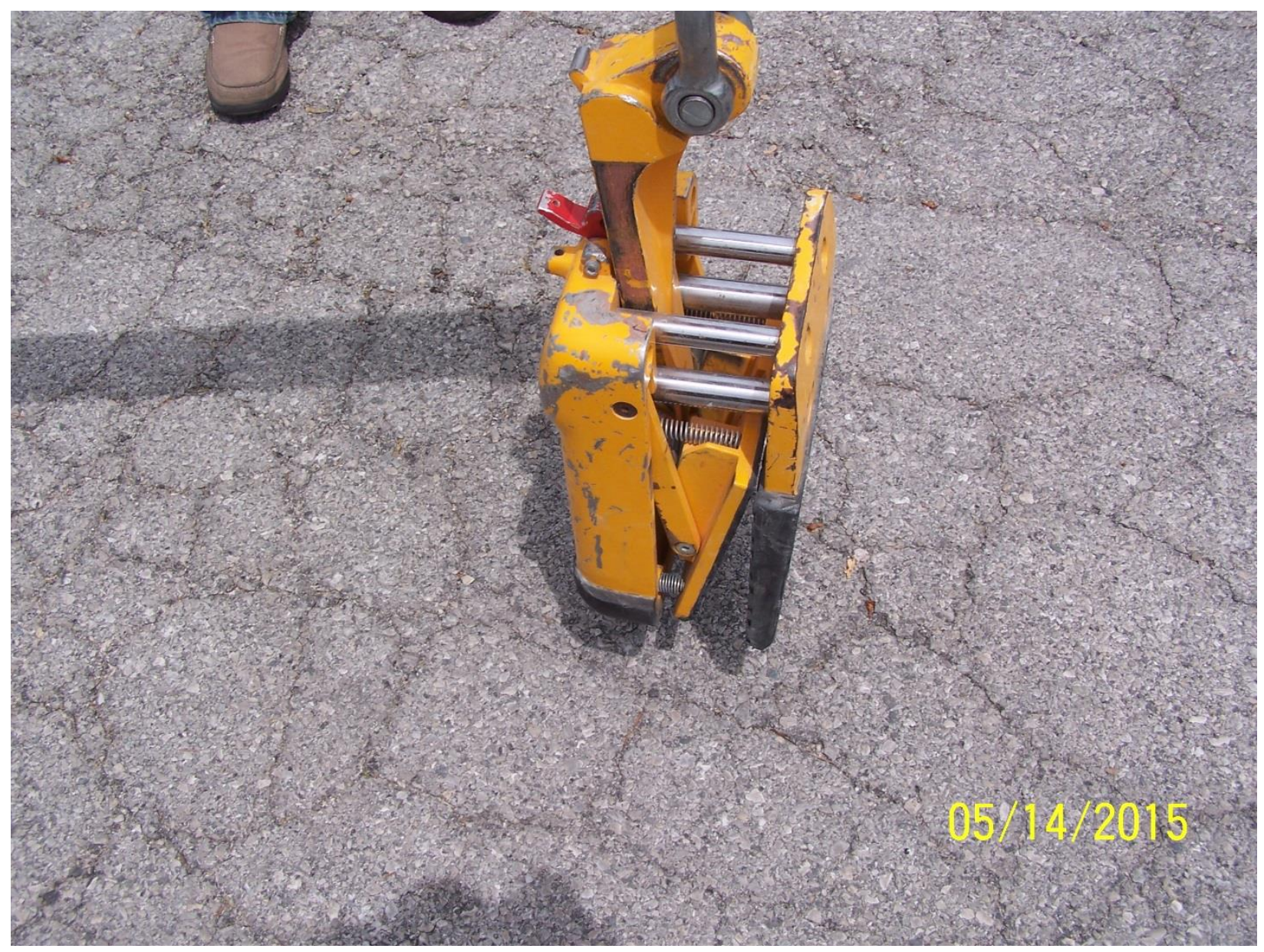

Photo \#2: The slab clamp

Photo Property of KY FACE Program 


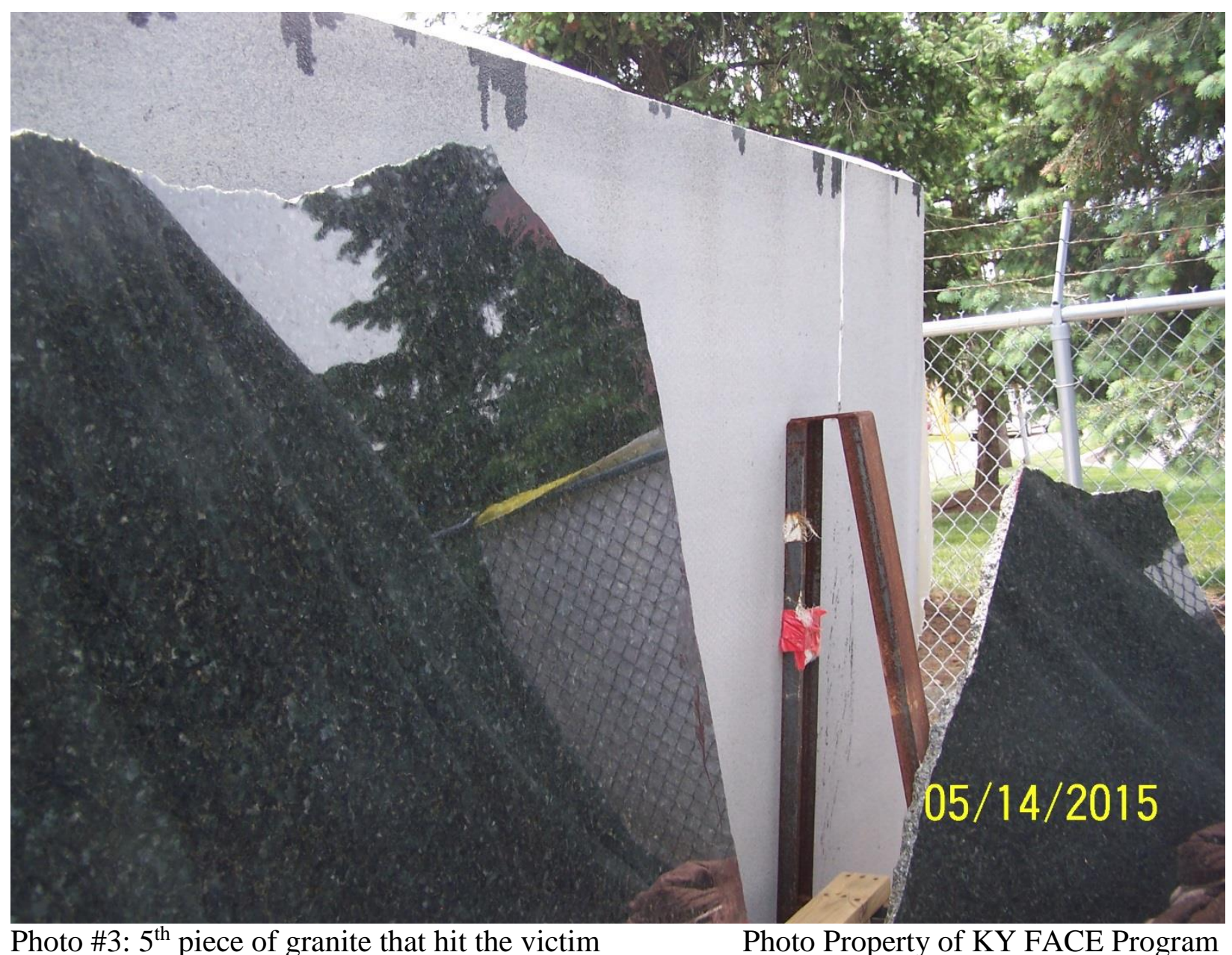




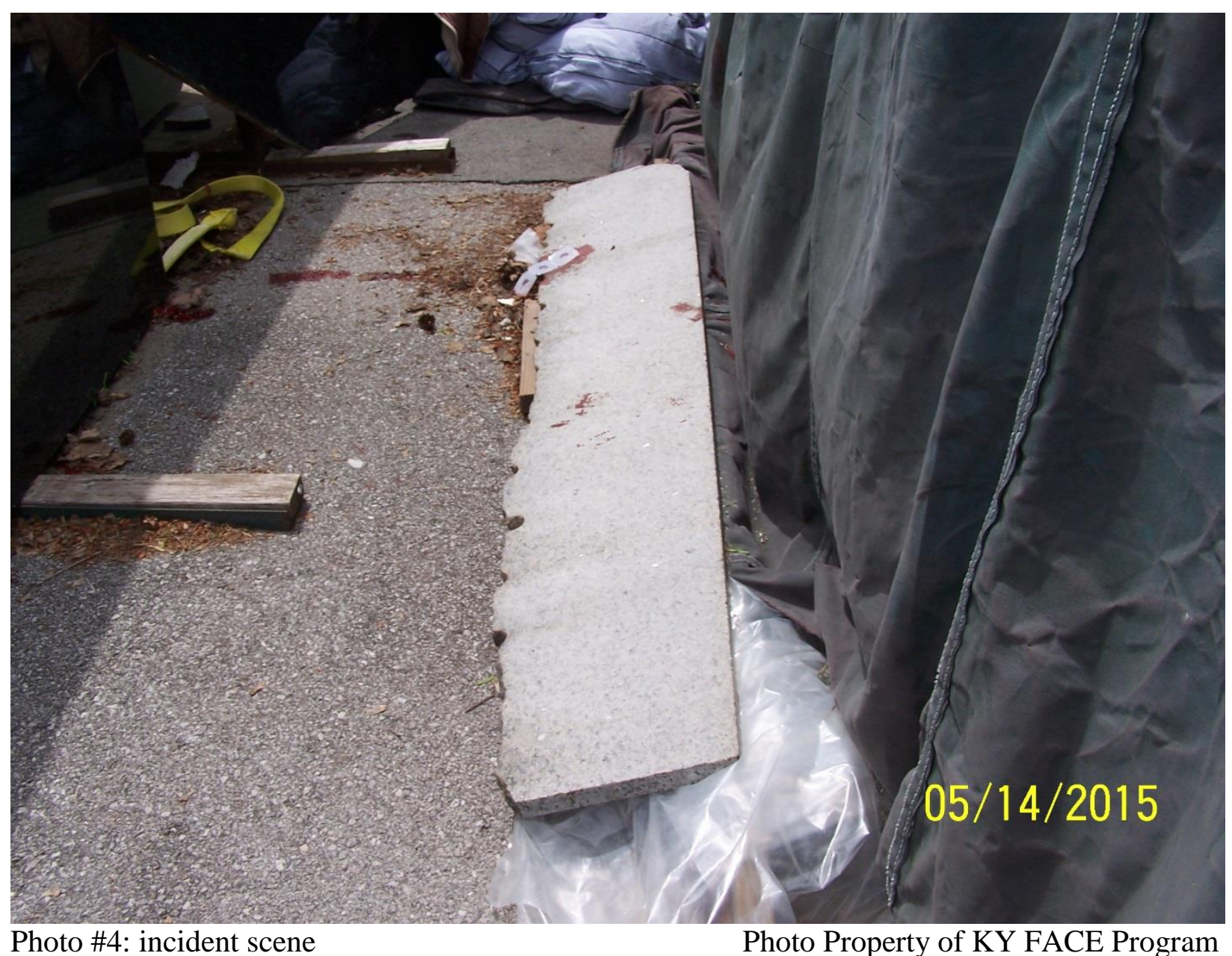




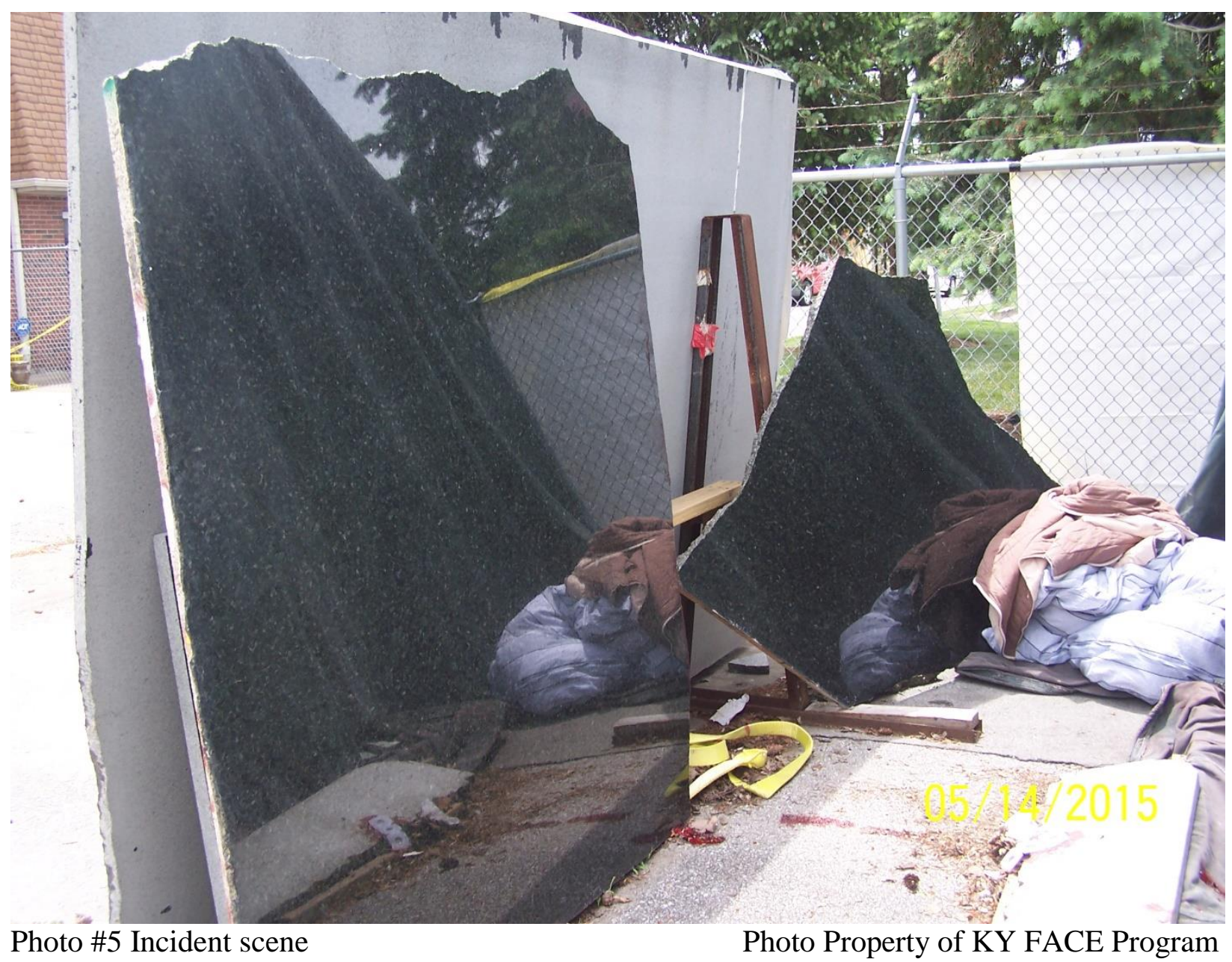

